\title{
CACHING BY AN IRRUPTIVE HAWK-OWL
}

DOUGLAS B. MCNAIR, 303 Robinson Street, Rockingham, North Carolina, USA. 28379

Red-breasted Nuthatches wintering outside their breeding range cache food. ${ }^{6}$ This fact was previously undocumented for any irruptive species that breeds in boreal forest. ${ }^{2}$ Northern Hawk-owls also have irruptive flights, though much less frequently and periodically than do Red-breasted Nuthatches, ${ }^{2,3,9,12}$ and feed principally on microtine rodents rather than conifer seeds and insects. ${ }^{7,10,14,15}$ Like other owls of the northern forest such as the Boreal Owl, Northern Hawkowls cache food in their breeding areas. ${ }^{7,8,11}$ Only one non-detailed report exists of a hawk-owl hiding a mouse in a dead tree in Minnesota, at a site where no breeding evidence was presented, though scattered nest records have occurred in the northern third of that state. ${ }^{12}$ Otherwise, food caching by Northern Hawk-owls has not been documented outside their breeding range.

Isolated in the Gulf of Saint Lawrence, the Magdalen Islands are within the boreal forest and sub-arctic biomes; the extent of forest is small and the Northern Hawk-owl is a vagrant here. ${ }^{4}$ Several records during summer 1978 suggested that the species may have nested; otherwise, only two reports exist, one from the winter of 1991-1992 when hawk-owls had a massive irruption into southern Quebec. ${ }^{1}$ I document herein the caching of a microtine rodent by a Northern Hawk-owl in the Magdalen Islands in spring 1992, during this same invasion period.

I discovered a Northern Hawk-owl at 10:15 a.m. on 2 May along the major highway (Route 99) $3 \mathrm{~km}$ south of Pointe-aux-Loups. The owl perched either on top of telephone poles or the lowest telephone wires and scanned for prey over the extensive open dunes, which were dominated by beach grass. Between 10:15 a.m. and 10:40 a.m., the bird left various perch sites on five fairly short, low hunting flights over the dunes. On its sixth attempt, the owl hovered $5 \mathrm{~m}$ above ground for 5 seconds, the only time hover-flight was used, and the next pounce was successful. The bird took 10 seconds to decapitate the microtine rodent and eat the brain. The owl then flew back to the lowest telephone wire near a pole.

The hawk-owl took four or five minutes to eat the anterior half of the rodent, including the skin and fur, though twice it let some intestinal matter fall to the ground. At 10:45 a.m., the hawk-owl took five seconds to store the posterior half of the rodent on a spool of the telephone pole where the lowest wire was attached; it flattened out the prey on the spool and fastened it in well, though I could see a portion of the prey on the spool. The bird then resumed hunting for 20 minutes, without success.

At 11:05 a.m., I simulated attempts for two minutes to climb the telephone pole which contained the cached rodent. The hawk-owl, which had been hunting from the top of a neighbouring telephone pole, flew to the topmost telephone wire directly above me (the only time the topmost 
wires were used) and repeatedly looked at me for one minute. Then the owl left the wire, emitted a single high-pitched squeal, snatched the rodent from the spool and flew to the top of the neighbouring telephone pole from whence it came. There, the owl finished eating by 11:15 a.m.

Food-caching behaviour by this vagrant Northern Hawk-owl, that is bringing the prey to a perch, feeding on and eviscerating the prey, and caching the uneaten portion on the spool of a telephone pole, is similar to caching behaviour in trees on its breeding grounds. ${ }^{7,11}$ On 2 May, the date that caching was observed in the Magdalen Islands, hawk-owls are normally on breeding territories in the north. ${ }^{5}$ The owl was not seen again on 2 May, nor afterwards, despite extensive search by myself and several local bird watchers. Consequently, this vagrant hawk-owl would not have been expected to store food over the long term. The hawkowl defended its cached food by vocalizing at a potential usurper and retrieving the rodent, which was originally procured using energetically expensive hover-flight. These behaviours suggested that the cached portion of the rodent was a valuable buffer against daily food shortages. 6,13

I thank A.J. Erskine and C.S. Houston for helpful comments on the manuscript.

1. AUBRY, Y. and R. YANK. 1992. Les observations saisonnieres: l'hiver 1991-1992. Quebec Oiseaux 4:23-26.

2. BOCK, C.E. and L.W. LEPTHIEN. 1976. Synchronous eruptions of boreal seed-eating birds. Am. Naturalist 110:559-571.

3. CATLING, P.M. 1972. A study of the Boreal Owl in southern Ontario with particular reference to the irruption of 1968-1969. Can. Field-Nat. 86:223232.

4. FRADETTE, P. 1992. Les oiseaux des lles-de-la-Madeleine: populations et sites d'observation. Attention Frag'iles: mouvement pur la valorisation du patrimoine naturel des isles. L'Etang-du-Nord, Iles-de-la-Madeleine, Quebec. 292 pp.

5. GODFREY, W.E. 1986. The birds of Canada. Revised edition. National Museum of Canada. 650 pp.

6. GRUBB, T.C. JR. and T.A. WAITE. 1987. Caching by Red-breasted Nuthatches. Wilson Bull. 99:696-699.

7. HUHTALA, K., E. KORPIMAKI and E. PULLIAINEN. 1987. Foraging activity and growth of nestlings in the hawk owl: adaptive strategies under northern condition. Pp. 152-156 in Biology and conservation of northern forest owls: symposium proceedings, R.W. Nero, R.J. Clark, R.J. Knapton, and R.H. Hume, eds. Gen. Tech. Rep./ RM-142,. Fort Collins, Colorado. U.S. Dept. Agri., Forest Serv., Rocky Mtn. For. and Range Expt. Sta. 309 pp.

8. KORPIMAKI, E. 1987. Prey caching of breeding Tengmalm's Owls $A e$ golius funereus as a buffer against temporary food shortage. Ibis 129:499-510.

9. LARSON, D.L. and C.E. BOCK. 1986. Eruptions of some North American boreal seedeating birds, 1901-1980. Ibis 128:137-140.

10. MIKKOLA, H. 1972. Hawk owls and their prey in northern Europe. British Birds 65:453-460.

11. RITCHIE, R.J. 1980. Food caching behavior of nesting wild hawk owls. Raptor Res. 14: 59-60.

12. ROBERTS, T.S. 1936. American hawk owl. Pp. 614-617 in The birds of Minnesota. Vol. 1. Univ. Minnesota Press, Minneapolis. 718 pp.

13. SHERRY, D.F. 1985. Food shortages by birds and mammals. Adv. Study Behav. 15:153-188.

14. SMITH, D.A. 1970. Observations on nesting hawk owls at the Mer Bleue, near Ottawa, Canada. Can. Field-Nat. 84:377-383.

15. SNYDER, N.F.R. and J.W. WILEY. 1976. Sexual size dimorphism in hawks and owls of North America. Ornithol. Monogr. No. 20, A.O.U. 96 pp. 